\title{
Publisher Correction to: The gender gap and healthcare: associations between gender roles and factors affecting healthcare access in Central Malawi, June-
} August 2017

\author{
Amee D. Azad ${ }^{1 *}$, Anthony G. Charles², Qian Ding ${ }^{3}$, Amber W. Trickey $^{3}$ and Sherry M. Wren ${ }^{1,4}$
}

\section{Correction to: Arch Public Health 78, 119 (2020) \\ https://doi.org/10.1186/s13690-020-00497-w}

The original publication [1] of this article a part of Fig. 2 was accidentally removed during the publication process. In this correction article the correct (Fig. 1) and incorrect (Fig. 2) version of Fig. 2 are published for reference. The original publication has been updated.

Figure 1 the correct version of Fig. 2.

Figure 2 the incorrect version of Fig. 2.

\section{Author details}

'Stanford University School of Medicine, 291 Campus Drive, Stanford, CA 94305, USA. University of North Carolina Department of Surgery, Chapel Hill, NC, USA. ${ }^{3}$ Stanford-Surgery Policy Improvement Research \& Education Center, Stanford, CA, USA. ${ }^{4}$ Palo Alto Veterans Healthcare System, Palo Alto, CA, USA.

Published online: 12 February 2021

\section{Reference}

1. Azad AD, Charles AG, Ding Q, et al. The gender gap and healthcare: associations between gender roles and factors affecting healthcare access in Central Malawi, June-August 2017. Arch Public Health. 2020;78:119. https://doi.org/10.1186/s13690-020-00497-w.

The original article can be found online at https://doi.org/10.1186/s13690020-00497-w.

* Correspondence: adazad@stanford.edu

${ }^{1}$ Stanford University School of Medicine, 291 Campus Drive, Stanford, CA 94305, USA

Full list of author information is available at the end of the article
Ready to submit your research? Choose BMC and benefit from:

- fast, convenient online submission

- thorough peer review by experienced researchers in your field

- rapid publication on acceptance

- support for research data, including large and complex data types

- gold Open Access which fosters wider collaboration and increased citations

- maximum visibility for your research: over 100M website views per year

At BMC, research is always in progress.

Learn more biomedcentral.com/submissions

(c) The Author(s). 2021 Open Access This article is licensed under a Creative Commons Attribution 4.0 International License, which permits use, sharing, adaptation, distribution and reproduction in any medium or format, as long as you give appropriate credit to the original author(s) and the source, provide a link to the Creative Commons licence, and indicate if changes were made. The images or other third party material in this article are included in the article's Creative Commons licence, unless indicated otherwise in a credit line to the material. If material is not included in the article's Creative Commons licence and your intended use is not permitted by statutory regulation or exceeds the permitted use, you will need to obtain permission directly from the copyright holder. To view a copy of this licence, visit http://creativecommons.org/licenses/by/4.0/. The Creative Commons Public Domain Dedication waiver (http://creativecommons.org/publicdomain/zero/1.0/) applies to the data made available in this article, unless otherwise stated in a credit line to the data. 

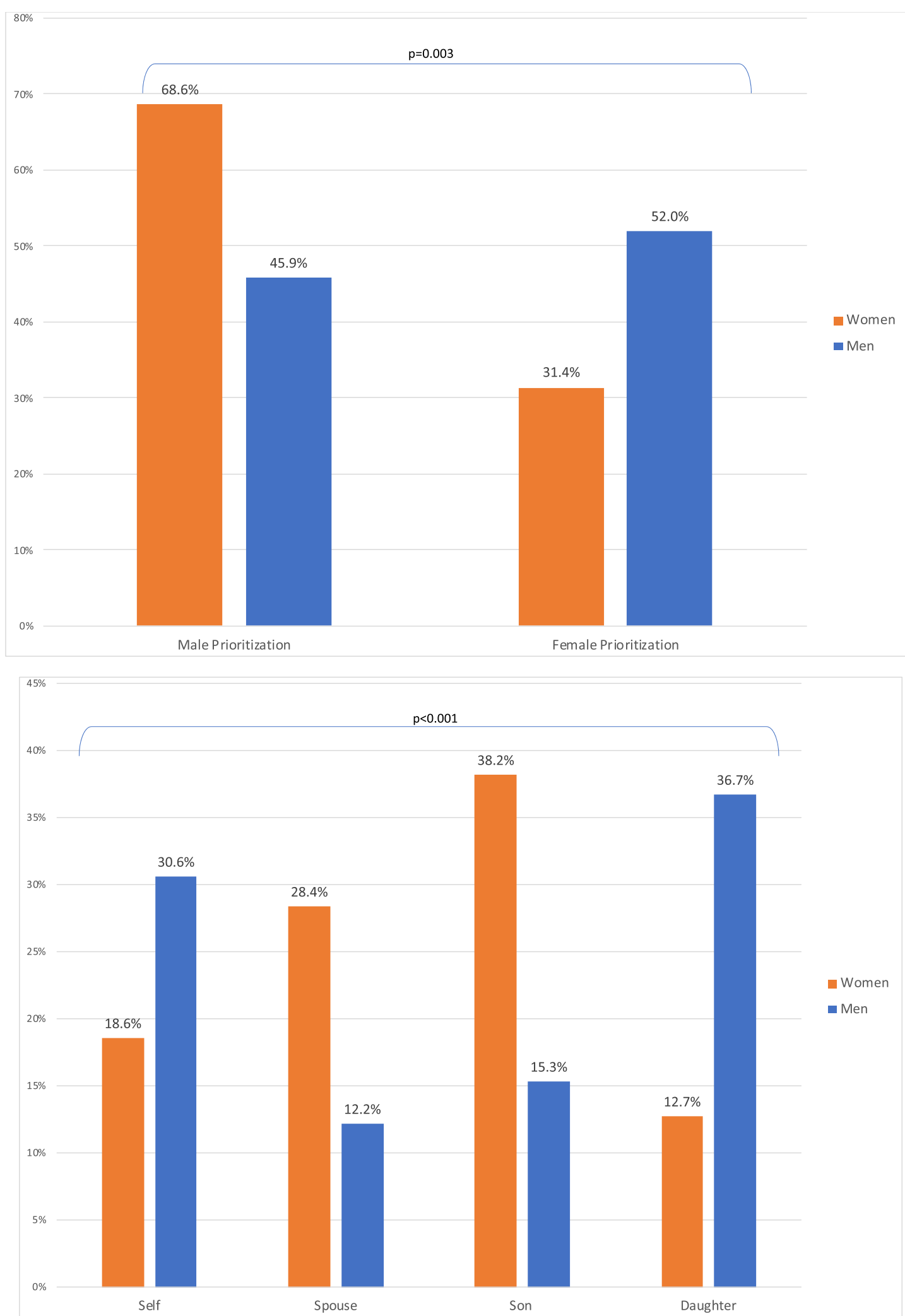

Fig. 1 Rates of access to and underutilization of healthcare in Lilongwe, Malawi, June-August 2017, a Gender differences in response to, "If you could not afford care, could you get financial support from your family or community? b Gender differences in response to, "Have you ever been seriously ill and chosen not to seek care?" 


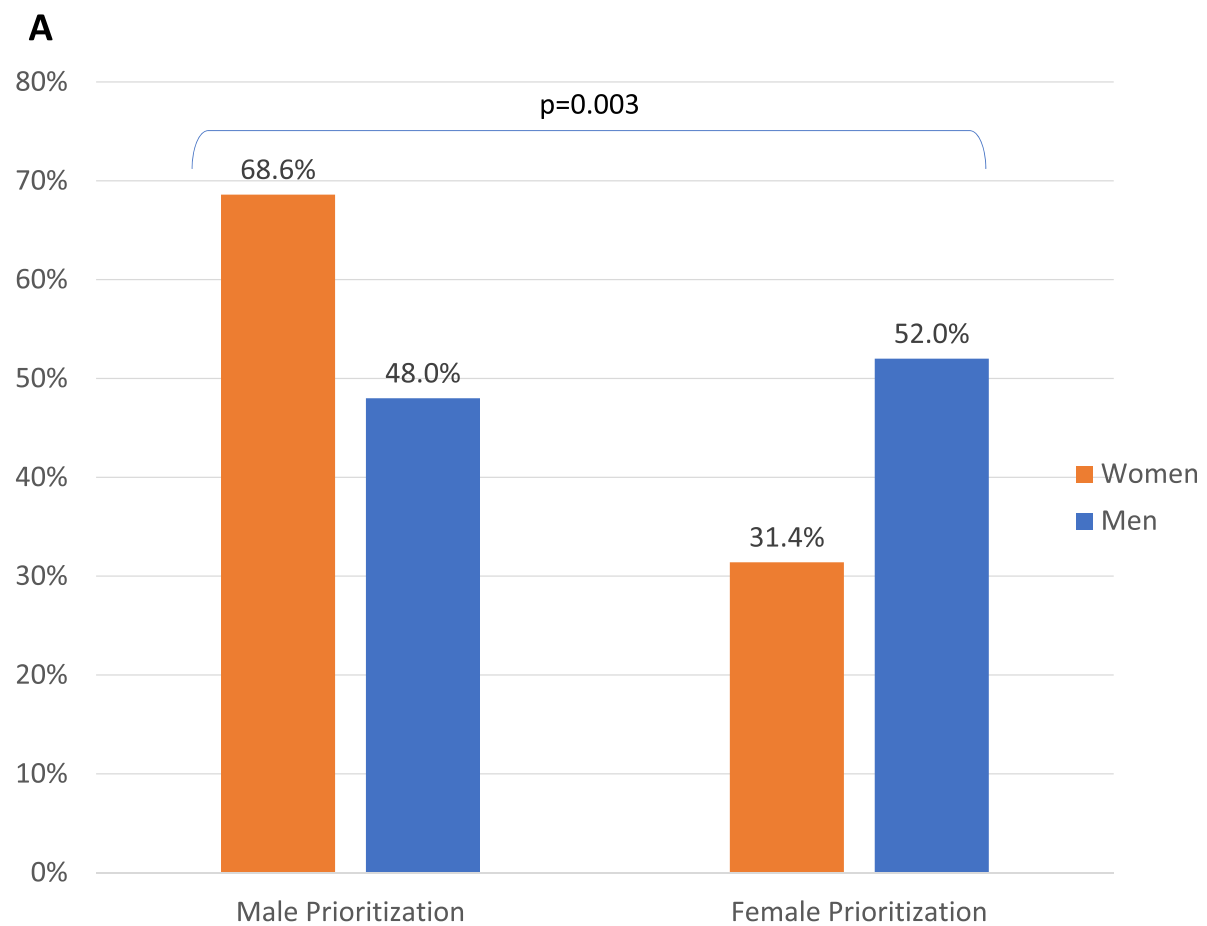

\section{B}

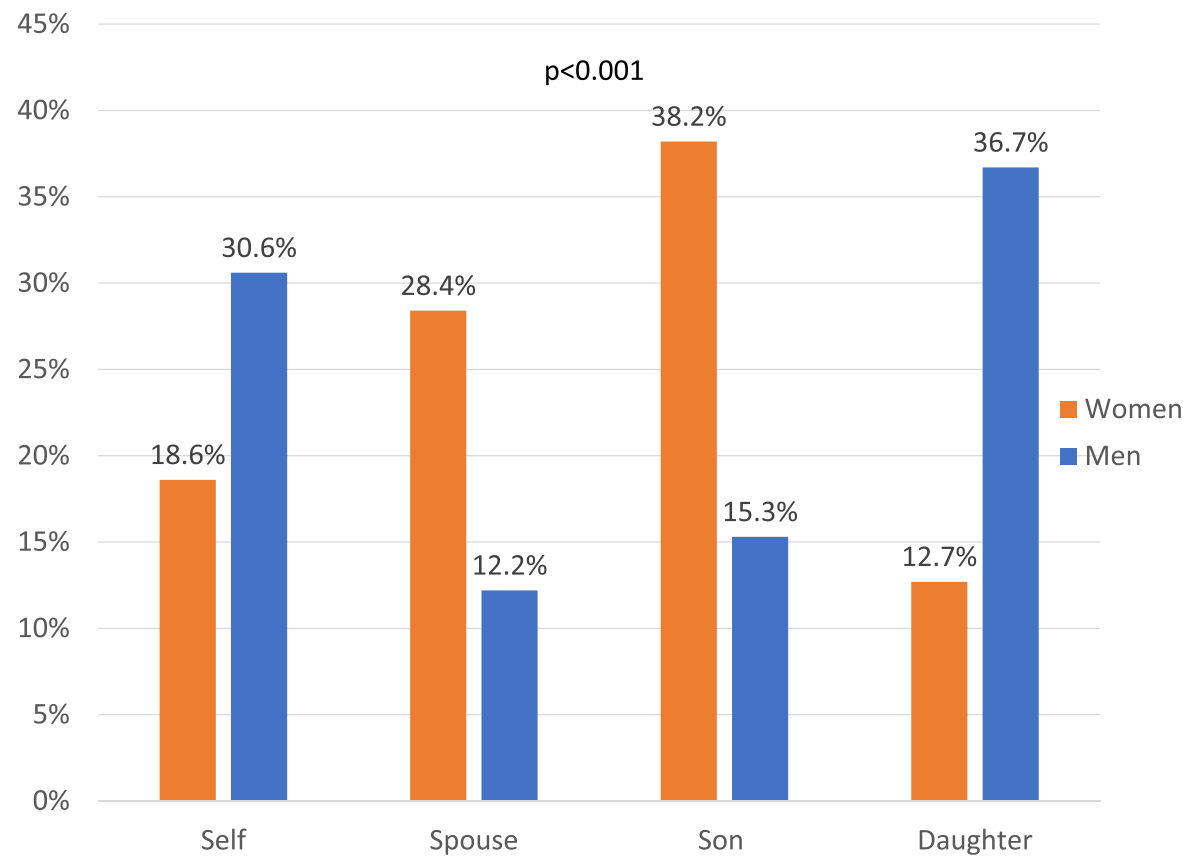

Fig. 2 a Distribution of Prioritization for Medical Treatment by Gender Prioritization in Lilongwe, Malawi, June-August 2017, b Distribution of Prioritization for Medical Treatment by Household Member in Lilongwe, Malawi, June-August 2017. Legend: Men (blue), Women (orange) 